\title{
Effect of Stress on the Martensitic Transformation in the $\mathrm{Cu}-\mathrm{Zn}$ System
}

\author{
by E. J. Suoninen, R. M. Genevray, and M. B. Bever
}

$\mathbf{T}$ $\mathrm{HE}$ martensitic transformation in the $\beta$-phase of the $\mathrm{Cu}-\mathrm{Zn}$ system has been the subject of several investigations. ${ }^{1-4}$ The transformation is known to be reversible and to be affected by stress. Its temperature range has been determined as a function of composition. In the investigation reported here, the effect of tensile stresses on the transformation was investigated quantitatively. Some information was also obtained on the thermoelastic behavior of the martensite formed in the first stages of the transformation.

Most of the experiments were done with alloy $E$ of an earlier investigation;" this alloy analyzed 60.49 pct $\mathrm{Cu}$ and 39.51 pct $\mathrm{Zn}$ by weight. The methods of shaping and heat treatment were also essentially the same as those previously used. The stress was applied to the specimen immersed in a cooling liquid. The transformation was followed by measuring the electrical resistance with a Kelvin bridge and the elongation with a cathetometer.

Fig. 1 shows the $M$, temperature as a function of stress. Resistance and strain measurements gave essentially identical values. The results suggest a roughly linear relation between $M$, and $\sigma$ in the

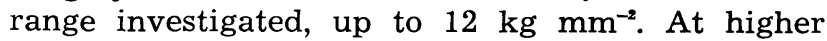
stresses, plastic deformation begins to interfere seriously with this relationship.

The increase of $M$, with stress is consistent with published work on the effect of stress on the martensitic transformation.". The slope of the curve, $4^{\circ} \mathrm{C}$ per $\mathrm{kg} \mathrm{mm} \mathrm{mm}^{-2}$, is of the same order of magnitude as the corresponding value calculated for steel. ${ }^{7}$

Fig. 1 also shows the difference, $\Delta M$, between the temperature of 50 pct transformation on cooling, as measured by changes in length, and that of 50 pct reverse transformation on heating. This difference, which may be considered a measure of the hysteresis, increases with stress; the decrease at highest stresses is probably associated with plastic deformation.

Preliminary work using only resistance measurements was done with an alloy containing 60.15 pct $\mathrm{Cu}$ and 39.79 pet $\mathrm{Zn}$ by weight. The results indicated higher values of $M$, in agreement with the known variation of $M$, with composition." The effect of stress on $M_{\text {, }}\left(2^{\circ} \mathrm{C}\right.$ per $\left.\mathrm{kg} \mathrm{mm} \mathrm{mm}^{-2}\right)$ was of the same order of magnitude as that shown in Fig. 1 for composition $E$. An increase in hysteresis with stress was also found.

The following experiment was made in order to investigate a partially transformed structure. A specimen of alloy $E$ was cooled to $-85^{\circ} \mathrm{C}$ under a stress of $4.7 \mathrm{~kg} \mathrm{~mm}^{-2}$. Under these conditions, the martensitic transformation started but did not go to completion. The stress was then released and the

E. J. SUONINEN is Graduate Student, Dept. of Metallurgy, Massachusetts Institute of Technology, R. M. GENEVRAY was formerly associated with Dept. of Metallurgy, Massachusetts Institute of Technology, and M. B. BEVER, Member AIME, is Associate Professor, Dept. of Metallurgy, Massachusetts Institute of Technology, Cambridge, Mass.

TN 298E. Manuscript, June 24, 1955.

This note is based on theses by E. J. Suoninen and R. M. Genevray submitted, in partial fulfillment of the requirements for the degree of Master of Science, to Massachusetts Institute of Technology.
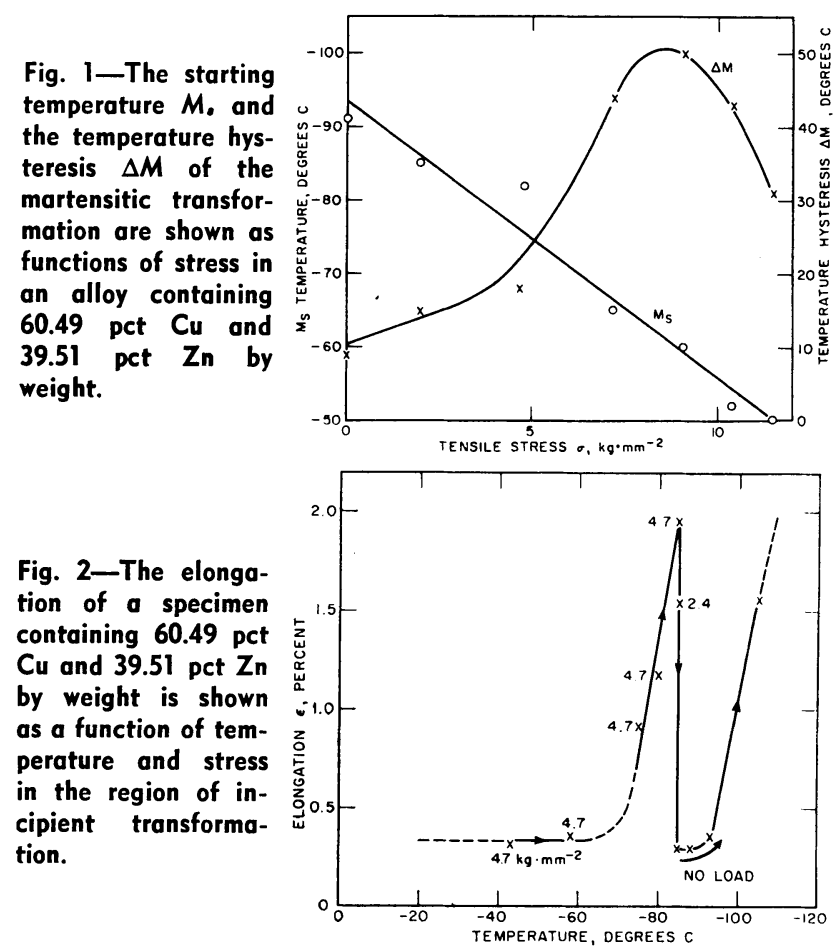

specimen cooled to $-105^{\circ} \mathrm{C}$. Fig. 2 shows the measured elongation $\epsilon$. The first change in the slope of the curve indicates the beginning of the transformation under stress. Removing the load at $-85^{\circ} \mathrm{C}$ caused a decrease in length to the value corresponding to the elastic elongation of the parent phase resulting from the applied stress. Hence, the martensite formed in the first part of the experiment apparently disappears completely and without hysteresis upon the release of the stress. The increase in length on further cooling indicates renewed formation of martensite. These conclusions are consistent with the concept of "thermoelastic" martensite, ${ }^{8}$ which has been confirmed by test. ${ }^{\circ}$

\section{Acknowledgments}

The authors are greatly indebted to Professor M. Cohen for his advice and encouragement. They also thank F. Paxton for assistance. Thanks are due the American Brass Co. which supplied the alloys.

\section{References}

${ }^{1}$ E. Kaminsky and G. V. Kurdjumov: Zhur. Tekhn. Fiziki SSSR (1936) 6, p. 984.

${ }^{2}$ A. B. Greninger and V. G. Mooradian: Trans. AIME (1938) 128, p. 337

${ }^{3}$ J. E. Reynolds, Jr. and M. B. Bever: Trans. AIME (1952) 194, p. 1065; Journal of Metals (October 1952).

4A. L. Titchener and M. B. Bever: Trans. AIME (1954) 200, p. 303; Journal of Metals (February 1954).

${ }^{5}$ S. A. Kulin, M. Cohen, and B. L. Averbach: Trans. AIME (1952) 194, p. 661; Journal of Metals (June 1952).

'J. R. Patel and M. Cohen: Acta Metallurgica (1953) 1, p. 531

${ }^{7}$ C. Crussard: Comptes Rendus (1953) 237, p. 1709.

${ }^{8}$ G. V. Kurdjumov: Zhur. Tekhn. Fiziki SSSR (1948) 18 , p. 999

${ }^{\circ}$ G. V. Kurdjumov and L. G. Khandros: Dokl. Akad. Nauk. SSSR (1949) 66, p. 211. 